\section{Response of Matthiola incana to Irrigation with Saline Wastewaters}

\author{
C.M. Grieve, ${ }^{1}$ J.A. Poss, and C. Amrhein ${ }^{2}$ \\ U.S. Department of Agriculture, Agricultural Research Service, George E. Brown, \\ Jr., Salinity Laboratory, 450 West Big Springs Road, Riverside, CA 92507
}

Additional index words. drainage water reuse, floriculture, ion selectivity, sand culture, stock

\begin{abstract}
Two cultivars of Matthiola incana (L.) R. Br. ('Cheerful White'and 'Frolic Carmine') were grown in greenhouse sand cultures to determine the effect of salt stress on growth, ion relations, and flower quality. Two types of irrigation waters, differing in ion composition, were prepared to simulate saline wastewaters commonly present in two inland valley locations in California. Solution ICV was typical of saline tailwaters frequently found in the Imperial and Coachella Valleys and contained $\mathrm{Cl}^{-}, \mathrm{Na}^{+}, \mathrm{SO}_{4}{ }^{2-}, \mathrm{Mg}^{2+}, \mathrm{Ca}^{2+}$, predominating in that order. Solution $\mathrm{SJV}$ was dominated by $\mathrm{Na}^{+}$and $\mathrm{SO}_{4}^{2-}$ and simulated saline drainage effluents often present in the San Joaquin Valley. Five treatments of each salinity type were imposed; each was replicated three times. Electrical conductivities of the irrigation waters $\left(E C_{i}\right)$ were $2.5,5,8,11$, and $14 \mathrm{dS} \cdot \mathrm{m}^{-1}$. Plant heights were determined weekly. Seedlings were sampled for ion analysis 9 weeks after planting. Flowering stems were harvested when about $50 \%$ of the florets in the inflorescence were open. Total stem length, weight and diameter, numbers of florets and buds, and inflorescence length were measured at final harvest. All plants remained healthy throughout the experimental period with no visible signs of ion toxicity or deficiency. Although length of the flowering stems decreased with increasing salinity, stems were of marketable quality even at the highest salinity level. Mineral ion composition of the vegetative tissues generally reflected ion concentrations in the irrigation waters. Shoot $\mathrm{Mg}^{2+}$ and $\mathrm{Cl}^{-}$were higher and shoot $\mathrm{Na}^{+}$lower in seedlings irrigated with ICV waters than with SJV waters. Shoot $P$ was reduced over control levels once salinity exceeded $11 \mathrm{dS} \cdot \mathrm{m}^{-1}$. Both cultivars were highly selective for $\mathrm{K}^{+}$over $\mathrm{Na}^{+}$and selectivity coefficients $\left(\mathrm{S}_{\mathrm{K}, \mathrm{Na}}\right)$ increase about $60 \%$ as salinity increased from 2.5 to $14 \mathrm{dS} \cdot \mathrm{m}^{-1}$. This study illustrates that commercially acceptable cut flowers of stock may be produced under irrigation with moderately saline wastewaters.
\end{abstract}

As quality and quantity of water resources become limited in many parts of the world, new options must be sought to make more efficient use of wastewaters. Because agriculture is the main user of our water supplies, there is strong interest in increasing the efficiency of water use through reuse options. Reuse of wastewaters would preserve greater amounts of high quality water and may also provide a resource for the production of selected high value horticultural crops, including vegetable, flower, herb, and medicinal species.

In California, $>300$ growers market cut flowers and foliage valued at almost $\$ 366$ million annually. These growers produce $60 \%$ of all domestically grown, commercially sold cut flowers in the United States (California Cut Flower Commission, 2003). Because many floricultural crops are salt sensitive, growers have traditionally used high-quality waters for irrigation. The availability of these water resources, however, is dwindling through

Received for publication 14 July 2005. Accepted for publication 14 Sept. 2005. The authors are indebted to Phyllis Nash for statistical analyses and to Donald A. Layfield for mineral ion analysis. Seed was donated by Sakata Seed America, Inc., Morgan Hill, Calif. This research was supported in part by a CAL-FED grant, administered by the California Department of Water Resources, Project Manager, Debra Gonzalez.

${ }^{1}$ To whom reprint requests should be addressed; e-mail cgrieve@ussl.ars.usda.gov.

${ }^{2}$ University of California, Department of Environmental Sciences, 214 Science, Laboratory 1 Riverside, CA 92521. competition between domestic, ecological and agricultural users. At the same time, the condition of water resources in many areas is deteriorating due to the build-up of salts and other contaminants. Floricultural crop producers must eventually develop innovative ways to manage available waters, including degraded waters, more judiciously. It becomes important, therefore, to identify floral species that will produce a commercially acceptable crop when irrigated with brackish wastewaters. This strategy, together with management practices that avoid salt accumulation in the root media, will provide the grower with a economically and environmentally sound water reuse options.

Several commercially important floral and ornamental crops possess some degree of salt tolerance. Growers have exploited this variability to that lack reliable sources of high quality water, e.g., the Netherlands, India, Spain, and Israel. Successes in breeding and selection techniques have been coupled withimprovedmethods of cultivation. As a result of these advances, cut flower crops such as Limonium, Dianthus, Gypsophila, Helianthus, Matthiola, and Chrysanthemum are routinely grown throughout the Negev desert of Israel in fields irrigated with local saline waters (Shillo et al., 2002).

All salinity effects on floriculture crops may not be negative. Salt stress often induces some favorable effects on crop yield, quality, and disease resistance. In some instances, uptake and accumulation of salinizing ions stimulate expand profitable cut flower industries in regions growth. Cabrera and Perdomo(2003) observed a positive correlation between relatively high leaf $\mathrm{Cl}$ concentrations $(0.45 \%)$ and dry weight in container-grown rose ('Bridal Pink' on Rosa manetti rootstock). Flower yield and quality components were unaffected. Salinity imposed early in the life cycle of some cut flower species tends to limit vegetative growth with positive results. For example, reduction of petiole length by salinity may beneficial in chrysanthemum production where tall cultivars are treated with growth regulators to keep the plants short. Lieth and Burger (1989) found that while plant height was reduced by salinity, developmental timing and inflorescence size were unaffected by stress. The authors suggest that imposition of salinity at appropriate stages of growth would reduce production costs by avoiding the use of growth inhibitors to control stem length.

Application of salinity after some optimum level of vegetative growth has been reached, tends to enhance reproductive growth and often improves crop quality. Shillo et al. (2004) reported that salinity imposed on Eustoma grandiflorum during the final stages of vegetative growth resulted in significant increases in numbers of flowers, stem weight and stem diameter. Another benefit of salt treatment was the production of more compact flower clusters, a desirable trait which prevents drooping of Eustoma inflorescences. Similar positive effects have been noted with carnation. Salt stress during early reproductive growth resulted in shorter, more robust peduncles with larger inflorescences compared to the nonsaline controls (Baas et al., 1995).

Many stock cultivars appear to be relatively salt tolerant (Heuer and Ravina, 2004). However, wide cultivar differences in sensitivity to chloride have been noted. For example, cultivar 'Ball lilac-lavender' was grown in soil cultures irrigated with a solution containing 5 $\mathrm{mM} \mathrm{Cl}^{-}$(Wigdor et al., 1958). Compared to the $\mathrm{Cl}$-free control, this relatively low $\mathrm{Cl}^{-}$concentration did not reduce stem length, but caused severe leaf tip and interveinal necrosis. In contrast, Lunt et al. (1954) evaluated the salt tolerance of six stock cultivars in soil cultures by comparing plant response to two chloridedominated irrigation solutions, i.e., $\mathrm{Cl}^{-}=85$ $\mathrm{mM}$ and $\mathrm{Cl}^{-}=171 \mathrm{mM}$. Flower quality was not affected and leaf injury was not observed until the $\mathrm{Cl}^{-}$concentration exceeded $85 \mathrm{~mm}$. Plants grown at the higher salinity were significantly shorter and the basal leaves were chlorotic.

In 2003, California growers produced 24 million stems of stock [Matthiola incana (L.) $\mathrm{R}$. Br.] with a retail value of about $\$ 6$ million (California Cut Flower Commission, 2003). This greenhouse study was designed to evaluate the effect of saline irrigation waters differing in ion composition on the ion relations, growth and yield of a commercially important cutflower crop.

\section{Materials and Methods}

Stock cultivars 'Cheerful White' and 'Frolic Carmine' were grown in greenhouse sand cultures. On 10 Jan. 2003, 20 seeds of each cultivar were planted in each of 30 sand 
Table 1. Composition of salinizing salts in solutions used to irrigate Matthiola incana grown in greenhouse sand cultures. Solution ICV was typical of saline tailwaters frequently found in the Imperial and Coachella Valleys and contained $\mathrm{Cl}^{-}, \mathrm{Na}^{+}, \mathrm{SO}_{4}^{2-}, \mathrm{Mg}^{2+}, \mathrm{Ca}^{2+}$, predominating in that order. Solution SJV was dominated by $\mathrm{Na}^{+}$and $\mathrm{SO}_{4}^{2-}$ and simulated saline drainage effluents often present in the San Joaquin Valley.

\begin{tabular}{|c|c|c|c|c|c|c|}
\hline \multirow{2}{*}{$\begin{array}{l}\text { EC } \\
\left(\mathrm{dS} \cdot \mathrm{m}^{-1}\right)\end{array}$} & \multirow{2}{*}{$\begin{array}{l}\text { Salinity } \\
\text { type }\end{array}$} & \multicolumn{5}{|c|}{ Salt $\left(\mathrm{mmol} \cdot \mathrm{L}^{-1}\right)$} \\
\hline & & $\mathrm{Ca}^{2+}$ & $\mathrm{Mg}^{2+}$ & $\mathrm{Na}^{+}$ & $\mathrm{SO}_{4}^{2-}$ & $\mathrm{Cl}^{-}$ \\
\hline 2.5 & Solution ICV ${ }^{2}$ & 2.6 & 3.0 & 10.6 & 3.3 & 13.2 \\
\hline 5 & & 4.8 & 7.7 & 26.6 & 8.3 & 34.8 \\
\hline 8 & & 7.6 & 12.7 & 43.6 & 13.6 & 57.2 \\
\hline 11 & & 10.0 & 17.9 & 61.0 & 19.1 & 80.2 \\
\hline 14 & & 13.5 & 23.5 & 81.0 & 25.2 & 107.0 \\
\hline 2.5 & Solution SJVy & 2.6 & 1.5 & 13.8 & 7.0 & 7.0 \\
\hline 5 & & 5.3 & 4.1 & 36.4 & 18.2 & 17.6 \\
\hline 8 & & 8.3 & 6.6 & 58.2 & 29.5 & 28.2 \\
\hline 11 & & 11.5 & 9.2 & 80.9 & 41.1 & 39.2 \\
\hline 14 & & 13.0 & 12.7 & 113 & 54.1 & 54.6 \\
\hline
\end{tabular}

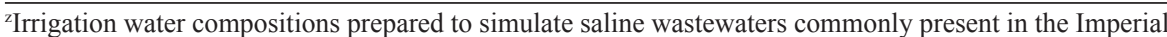
and Coachella Valleys of California.

y Irrigation water compositions prepared to simulate saline wastewaters commonly present in the San Joaquin Valley of California.

tanks. The tanks $(1.2 \times 0.6 \times 0.5 \mathrm{~m}$ deep $)$ contained washed sand having an average bulk density of $1.7 \mathrm{Mg} \cdot \mathrm{m}^{-3}$. At saturation the sand had an average volumetric water content of $0.34 \mathrm{~m}^{3} \cdot \mathrm{m}^{-3}$, and $0.1 \mathrm{~m}^{3} \cdot \mathrm{m}^{-3}$ after drainage, had nearly ceased. Plants were irrigated three times daily with complete nutrient solution with an electrical conductivity (EC) of $2.5 \mathrm{dS} \cdot \mathrm{m}^{-1}$. In addition to the ions shown in Table 1 for this nonsaline control treatment, the irrigation waters also contained $\mathrm{KNO}_{3}(3 \mathrm{~mm}), \mathrm{KH}_{2} \mathrm{PO}_{4}$
(0.340 $\mathrm{mM})$ and the following micronutrients (in $\mu \mathrm{M}$ ): chelated-Fe $50, \mathrm{H}_{3} \mathrm{BO}_{3} 23, \mathrm{MnSO}_{4} 5$, $\mathrm{ZnSO}_{4} 0.4, \mathrm{CuSO}_{4} 0.2$, and $\mathrm{H}_{2} \mathrm{MoO}_{4} 0.1$ made up with City of Riverside municipal water $\left(\mathrm{EC}=0.6 \mathrm{dS} \cdot \mathrm{m}^{-1}\right)$. Irrigations were of $15 \mathrm{~min}$ duration, which allowed the sand to become completely saturated, after which the solutions drained to 765 -L reservoirs for reuse in the next irrigation. Water lost by evaporation was replenished automatically each day to maintain constant ECs in the solutions.
Two irrigation water types were used to simulate typical compositions of saline wastewaters present in two inland valley areas of California and from predictions based on appropriate simulations of what the long-term composition of the water would be upon further concentrations by plant-water extractions and evapotranspiration (Suarez and Simunek, 1997). Fifteen sand tanks were irrigated with solution ICV, whose composition was prepared to mimic major ions in $\mathrm{Cl}$-dominated saline tailwaters found in the Imperial and Coachella Valleys. The remaining 15 sand tanks were irrigated with solution SJV typical of the saline-sodic effluents common to the western San Joaquin Valley (Table 1).

Salinization of the solutions commenced on 27 Jan. 2003 when the first true leaves were fully expanded on $>50 \%$ of the seedlings. The rationale for delaying salinization was based on the assumption that a source of good-quality water would be available to the grower during stand establishment of the crop, and that thereafter the crop would be irrigated with degraded waters. Salt concentration in the nutrient solution was incrementally increased over $8 \mathrm{~d}$ to avoid osmotic shock to the seedlings. Final electrical conductivities (EC) of the irrigation waters were 2.5, 5, 8, 11, and $14 \mathrm{dS} \cdot \mathrm{m}^{-1}$. The experimental design was two irrigation water types (solutions SJV and

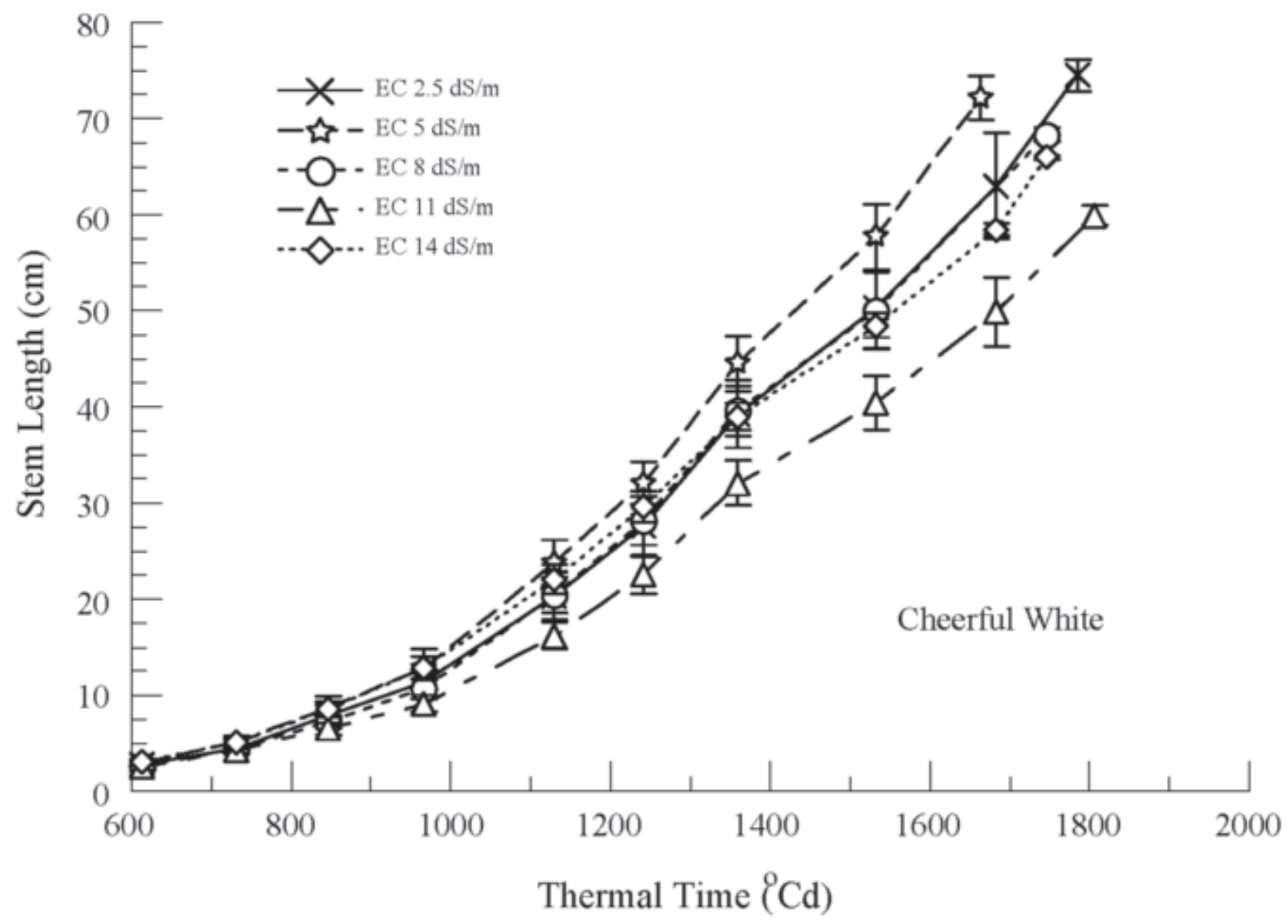

Fig. 1. Stem length of Matthiola incana ('Cheerful White') as a function of thermal time after planting. Irrigation waters were prepared to simulate saline wastewaters commonly present in the Imperial and Coachella Valleys of California. Values are the means of 30 observations \pm SE. 
ICV), six salinity levels, two stock cultivars, and three replications.

Irrigation waters were analyzed by inductively coupled plasma optical emission spectrometry (ICPOES) four times during the experiment to confirm that target ion concentrations were maintained. Chloride was determined by coulometric-amperometric titration.

Standard meteorological measurements were made in the greenhouse with a Class 1 agrometerological station.. Ambient daytime air temperatures in the greenhouse during the experiment ranged from 8.4 to $36.0^{\circ} \mathrm{C}$ (mean $\left.=22.3^{\circ} \mathrm{C}\right)$; nighttime temperatures ranged from 6.6 to $25.5^{\circ} \mathrm{C}\left(\right.$ mean $\left.=14.7^{\circ} \mathrm{C}\right)$. Relative humidity ranged from $42.8 \%$ to $47.5 \%$ with a mean of $45.4 \%$ during the day and $45.7 \%$ during the night. Daylength ranged from 10 h $11 \mathrm{~min}$ to $13 \mathrm{~h} 45 \mathrm{~min}$. The $\mathrm{pH}$ of the solutions was slightly alkaline and ranged between 7.8 and 8.4.

Shoot vegetative tissues were sampled for mineral ion analysis on 12 Mar. 2003. Samples were weighed, washed in deionized water, dried in a forced-air oven at 70 ${ }^{\circ} \mathrm{C}$ for $72 \mathrm{~h}$, then reweighed, and ground to pass a 60 -mesh screen. Total $\mathrm{S}$, total $\mathrm{P}$, $\mathrm{Ca}^{2+}, \mathrm{Mg}^{2+}, \mathrm{Na}^{+}$, and $\mathrm{K}^{+}$were determined on nitric-perchloric acid digests of the tissues by ICPOES. Chloride was determined on nitric-acetic acid extracts by coulometricamperometric titration.

Stems were harvested when about $50 \%$ of the flowers in the inflorescence were open (Armitage, 1993). Harvesting began 7 Mar. and continued until 7 May 2003. Plant measurements taken at this time were stem length and weight, inflorescence length, numbers of flowers and buds on the main inflorescence, and diameter of the largest flower in the spike. Stem diameter was measured $5 \mathrm{~cm}$ above the sand level.

Ion selectivity coefficients were calculated from the ratio of specific ions in the plant divided by the ratio of those ions in the external medium (Flowers and Yeo, 1985). Daily thermal units $\left(T_{u}\right)$ were calculated from daily maximum $\left(\mathrm{T}_{\max }\right)$ and minimum $\left(\mathrm{T}_{\min }\right)$ air temperatures above a base temperature $\left(T_{b}\right)$ following Hodges (1991): $T_{u}=\left[\left(T_{\max }+\right.\right.$ $\left.\left.\mathrm{T}_{\min }\right) / 2\right] / \mathrm{T}_{\mathrm{b}}$, where $\mathrm{T}_{\mathrm{b}}$ is assumed to be $0{ }^{\circ} \mathrm{C}$. The sum of $\mathrm{T}_{u}$ provided cumulative thermal units $\left(\sum \mathrm{T}_{\mathrm{u}}\right)$, expressed in degree Celsius days ( ${ }^{\circ} \mathrm{C}$ days).

Statistical analyses were performed by analysis of variance with mean comparisons at the $95 \%$ level based on Tukey's studentized range test. SAS release version 8.02 was used (SAS Institute, Inc., 2001).

\section{Results and Discussion}

Growth and yield. Throughout the course of the present study, both cultivars remained healthy in all treatments with no visible signs of ion toxicities or nutrient deficiencies.

Dry weights of shoots harvested 6 weeks after application of salinity were not significantly reduced by treatment. Regardless of cultivar, salinity level, or solution ion composition, mean shoot dried weight was $1.6 \mathrm{~g} /$ plant (data not shown). However, treatment effects on stem elongation were evident as early as four weeks after salinization (i.e., $\sum \mathrm{T}_{u}=1425^{\circ} \mathrm{C}$ d). For example, stem lengths of 'Cheerful White' (Fig. 1) and 'Frolic Carmine' (Fig. 2) irrigated with the most saline ICV waters $\left(\mathrm{EC}=14 \mathrm{dS} \cdot \mathrm{m}^{-1}\right)$ were significantly shorter than those under treatment with nonsaline control waters.

Stem length, measured at final harvest, showed the effects of salinity, e.g., length of 'Cheerful White' stems of plants irrigated with ICV waters decreased from 75 to $66 \mathrm{~cm}$ as salinity increased from 2.5 to $14 \mathrm{dS} \cdot \mathrm{m}^{-1}$. Stems of 'Frolic Carmine' were significantly shorter than those of 'Cheerful White', ranging from 69 to $62 \mathrm{~cm}$ as the EC of ICV irrigation waters increased to $14 \mathrm{dS} \cdot \mathrm{m}^{-1}$. The effect of salinity on plant growth as a function of thermal time under treatment is shown in Fig. 1 ('Cheerful

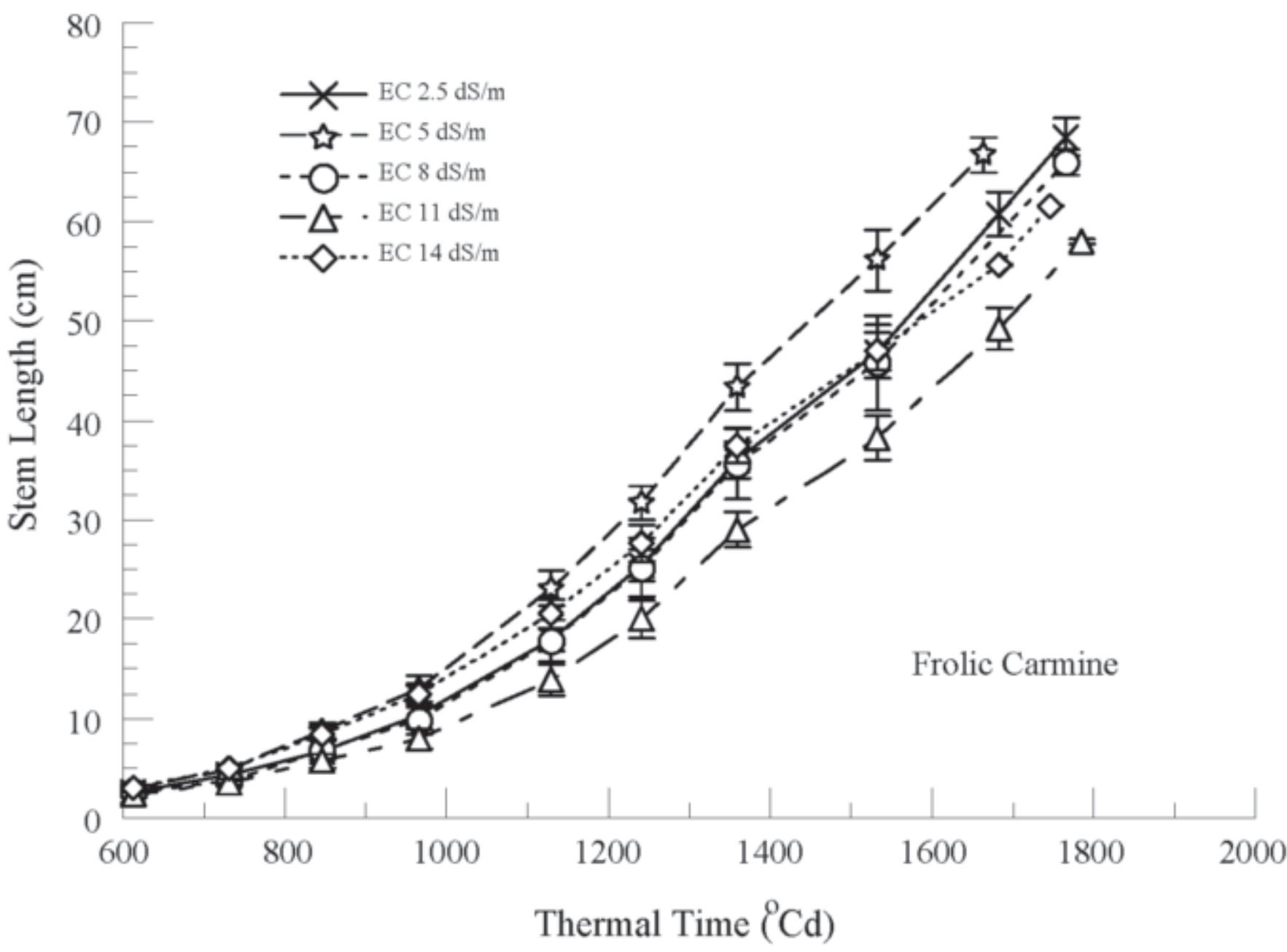

Fig. 2. Stem length of Matthiola incana ('Frolic Carmine') as a function of thermal time after planting. Irrigation waters were prepared to simulate saline wastewaters commonly present in the Imperial and Coachella Valleys of California. Values are the means of 30 observations \pm SE. 
Table 2. Growth parameters of stock grown determined at final harvest. Plants were grown in greenhouse sand tanks with two types of irrigation waters and five salinity levels. Solution ICV was typical of saline tailwaters frequently found in the Imperial and Coachella Valleys and contained $\mathrm{Cl}^{-}, \mathrm{Na}^{+}, \mathrm{SO}_{4}^{2-}, \mathrm{Mg}^{2+}, \mathrm{Ca}^{2+}$, predominating in that order. Solution SJV was dominated by $\mathrm{Na}^{+}$and $\mathrm{SO}_{4}{ }^{2-}$ and simulated saline drainage effluents often present in the San Joaquin Valley.

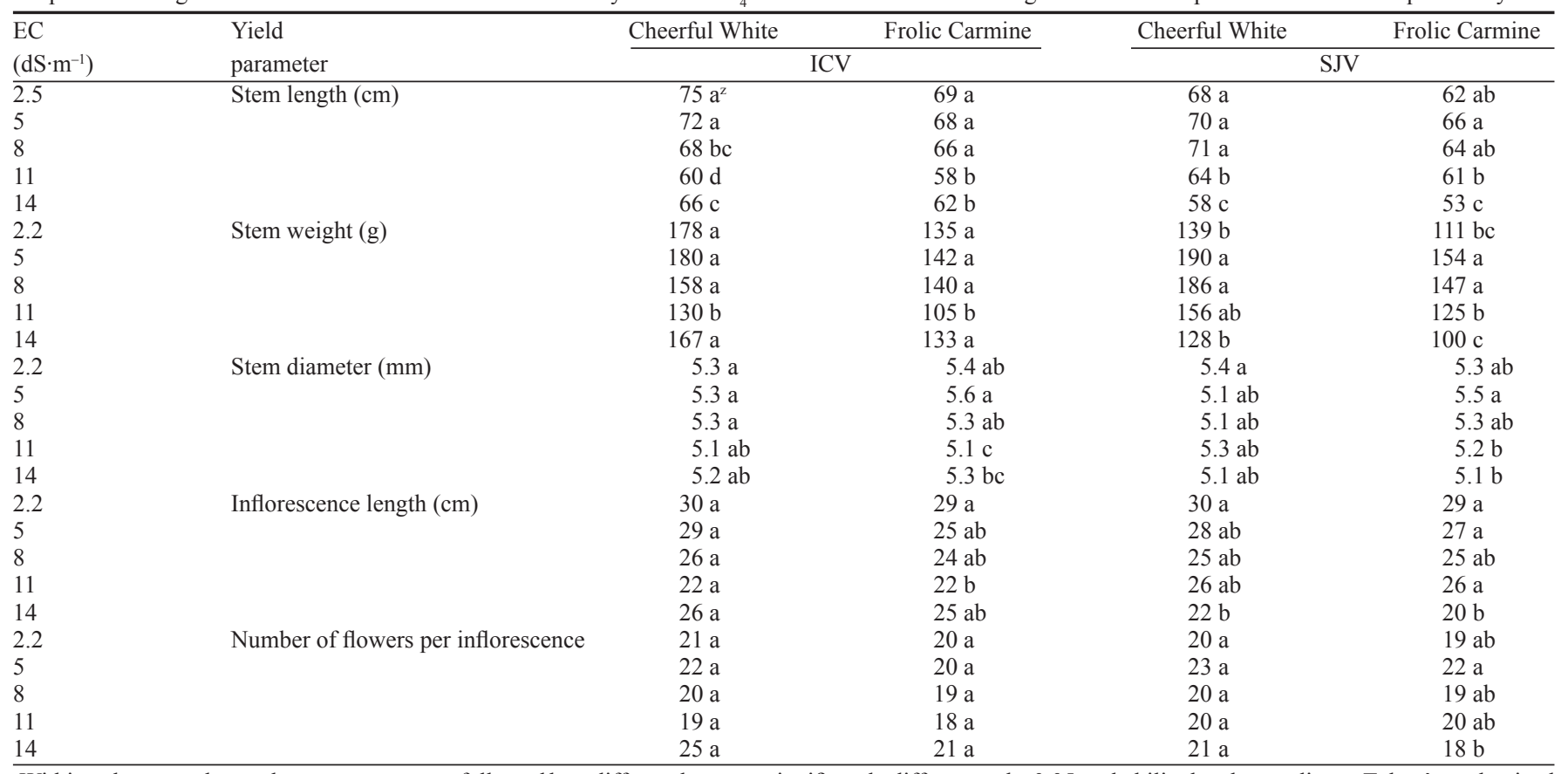

${ }^{2}$ Within columns and growth parameter, means followed by a different letter are significantly different at the 0.05 probability level according to Tukey's studentized range test. Values are the means of 30 observations.

White') and Fig. 2 ('Frolic Carmine') irrigated with ICV waters.

Salinity had little effect on weight of the flowering stems, stem diameter, inflorescence length and numbers of flowers per inflorescence. With the exception of inflorescence length of both cultivars irrigated with SJV waters, trends in plant growth components due to treatment were not significant (Table 2).

Stem length of flowers is an important criteria for consumer acceptability. All the flowering stems harvested at $50 \%$ bloom in this evaluation trial were well in excess of industry standards for marketability (Barr, 1992) and would quickly reach even more desirable lengths postharvest. In addition, the inflorescences with short internodes and densely packed florets were of superior quality in all treatments.

Shoot ion concentrations and interactions. Calcium status in plants is strongly influenced by the presence by the ionic composition of the external medium. Other salinizing ions in the substrate may reduce $\mathrm{Ca}^{2+}$ activity and limit the availability of $\mathrm{Ca}^{2+}$ to the plant. (Suarez and Grieve, 1988). Cations such as $\mathrm{Na}^{+}$and $\mathrm{Mg}^{2+}$ may displace $\mathrm{Ca}^{2+}$ from its extracellular binding sites within plant organs to further disrupt $\mathrm{Ca}^{2+}$ acquisition, uptake and transport. Shoot $\mathrm{Ca}^{2+}$ decreased significantly as salinity increased, despite a four-fold increase in external $\mathrm{Ca}^{2+}$ (Tables 3 and 4). Calcium was strongly accumulated in stock shoots, a trait that is shared by many other members of the family, Brassicaceae, and these concentrations were evidently high enough to prevent physiological disorders commonly associated with salinity-induced $\mathrm{Ca}^{2+}$ deficiency (Grattan and Grieve, 1999).

Shoot $\mathrm{Mg}^{2+}$ in stock irrigated with saline
ICV increased as salinity increased, but not to the extent that might be anticipated from the nearly 7 -fold increase of external $\mathrm{Mg}^{2+}$.

An even more striking response in shoot $\mathrm{Mg}$ occurred in response to irrigation with saline SJV waters. An 8-fold increase in substrate- $\mathrm{Mg}$

Table 3. Effect of increasing salinity on shoot ion concentrations in two Matthiola incana (L.) R. Br. cultivars in response saline irrigation waters with ion compositions typical of those present in the Imperial and Coachella Valleys of California (Solution A).

\begin{tabular}{lllccccl}
\hline EC & \multicolumn{7}{c}{ Ion concn $\left(\mathrm{mmol} \cdot \mathrm{kg}^{-1}\right.$ dry wt } \\
\cline { 2 - 7 }$\left(\mathrm{dS} \cdot \mathrm{m}^{-1}\right)$ & $\mathrm{Ca}$ & $\mathrm{Mg}$ & $\mathrm{Na}$ & $\mathrm{K}$ & $\mathrm{P}$ & $\mathrm{S}$ & $\mathrm{Cl}$ \\
\hline Cheerful White & & & & & & & \\
2 & $524 \mathrm{a}$ & $193 \mathrm{~b}$ & $539 \mathrm{~d}$ & $1174 \mathrm{a}$ & $422 \mathrm{a}$ & $216 \mathrm{~b}$ & $159 \mathrm{c}$ \\
5 & $431 \mathrm{~b}$ & $233 \mathrm{ab}$ & $985 \mathrm{c}$ & $1035 \mathrm{~b}$ & $413 \mathrm{a}$ & $229 \mathrm{ab}$ & $326 \mathrm{bc}$ \\
8 & $460 \mathrm{~b}$ & $282 \mathrm{a}$ & $1252 \mathrm{~b}$ & $949 \mathrm{~b}$ & $433 \mathrm{a}$ & $218 \mathrm{~b}$ & $448 \mathrm{abc}$ \\
11 & $420 \mathrm{~b}$ & $224 \mathrm{ab}$ & $1594 \mathrm{a}$ & $707 \mathrm{c}$ & $446 \mathrm{a}$ & $206 \mathrm{~b}$ & $617 \mathrm{ab}$ \\
14 & & & & $288 \mathrm{~b}$ & $251 \mathrm{a}$ & $721 \mathrm{a}$ \\
Frolic Carmine & $536 \mathrm{a}$ & $180 \mathrm{c}$ & $644 \mathrm{~d}$ & $1125 \mathrm{a}$ & $353 \mathrm{a}$ & $199 \mathrm{~b}$ & $182 \mathrm{~d}$ \\
2 & $530 \mathrm{a}$ & $224 \mathrm{~b}$ & $1058 \mathrm{c}$ & $940 \mathrm{~b}$ & $351 \mathrm{a}$ & $217 \mathrm{~b}$ & $377 \mathrm{~cd}$ \\
5 & $442 \mathrm{~b}$ & $251 \mathrm{ab}$ & $1343 \mathrm{~b}$ & $849 \mathrm{bc}$ & $369 \mathrm{a}$ & $204 \mathrm{~b}$ & $492 \mathrm{bc}$ \\
8 & $435 \mathrm{~b}$ & $264 \mathrm{a}$ & $1566 \mathrm{ab}$ & $770 \mathrm{c}$ & $355 \mathrm{a}$ & $210 \mathrm{~b}$ & $710 \mathrm{ab}$ \\
11 & $378 \mathrm{~b}$ & $235 \mathrm{ab}$ & $1727 \mathrm{a}$ & $654 \mathrm{~d}$ & $202 \mathrm{~b}$ & $243 \mathrm{a}$ & $916 \mathrm{a}$ \\
\hline
\end{tabular}

${ }^{2}$ Within columns and cultivars, means followed by a different letter are significantly different at the 0.05 probability level according to Tukey's studentized range test. Values are the means of three replications.

Table 4. Effect of increasing salinity on shoot-ion concentrations in two Matthiola incana (L.) R. Br. cultivars in response saline irrigation waters with ion compositions typical of those present in the San Joaquin Valley of California (Solution B).

\begin{tabular}{|c|c|c|c|c|c|c|c|}
\hline \multirow{2}{*}{$\begin{array}{l}\mathrm{EC} \\
\left(\mathrm{dS} \cdot \mathrm{m}^{-1}\right)\end{array}$} & \multicolumn{7}{|c|}{ Ion concn ( $\mathrm{mmol} \cdot \mathrm{kg}^{-1}$ dry wt) } \\
\hline & $\mathrm{Ca}$ & $\mathrm{Mg}$ & $\mathrm{Na}$ & $\mathrm{K}$ & $\mathrm{P}$ & $\mathrm{S}$ & $\mathrm{Cl}$ \\
\hline \multicolumn{8}{|c|}{ Cheerful White } \\
\hline 2.5 & $670 a^{z}$ & $163 \mathrm{a}$ & $822 \mathrm{~d}$ & $1047 \mathrm{a}$ & $503 \mathrm{a}$ & $230 \mathrm{~b}$ & $172 \mathrm{c}$ \\
\hline 5 & $534 \mathrm{~b}$ & $148 \mathrm{a}$ & $1263 \mathrm{c}$ & $921 \mathrm{~b}$ & $372 \mathrm{bc}$ & $251 \mathrm{ab}$ & $233 \mathrm{c}$ \\
\hline 8 & $475 \mathrm{bc}$ & $150 \mathrm{a}$ & $1506 \mathrm{bc}$ & $800 \mathrm{bc}$ & $378 \mathrm{bc}$ & $223 \mathrm{~b}$ & $286 \mathrm{bc}$ \\
\hline 11 & $406 \mathrm{c}$ & $167 \mathrm{a}$ & $1627 \mathrm{~b}$ & $715 \mathrm{~cd}$ & $328 \mathrm{c}$ & $240 \mathrm{ab}$ & $405 \mathrm{ab}$ \\
\hline 14 & $437 \mathrm{c}$ & $156 \mathrm{a}$ & $2068 \mathrm{a}$ & $645 \mathrm{~d}$ & $440 a b$ & $266 \mathrm{a}$ & $474 \mathrm{a}$ \\
\hline \multicolumn{8}{|c|}{ Frolic Carmine } \\
\hline 2.5 & $657 \mathrm{a}$ & 136 a & $857 \mathrm{e}$ & $1024 \mathrm{a}$ & $434 \mathrm{a}$ & $223 \mathrm{~b}$ & $171 \mathrm{c}$ \\
\hline 5 & $506 \mathrm{~b}$ & $131 \mathrm{a}$ & $1234 \mathrm{~d}$ & $868 \mathrm{~b}$ & $294 \mathrm{c}$ & $234 \mathrm{ab}$ & $242 \mathrm{~b}$ \\
\hline 8 & $434 \mathrm{bc}$ & $132 \mathrm{a}$ & $1464 \mathrm{c}$ & $791 \mathrm{~b}$ & $308 \mathrm{bc}$ & $211 \mathrm{c}$ & $273 \mathrm{~b}$ \\
\hline 11 & $441 \mathrm{bc}$ & $133 \mathrm{a}$ & $1803 \mathrm{~b}$ & $643 \mathrm{c}$ & $315 \mathrm{bc}$ & $237 \mathrm{ab}$ & $416 \mathrm{a}$ \\
\hline 14 & $408 \mathrm{c}$ & $140 \mathrm{a}$ & $2138 \mathrm{a}$ & $569 \mathrm{c}$ & $357 \mathrm{~b}$ & $244 \mathrm{a}$ & $407 \mathrm{a}$ \\
\hline
\end{tabular}

${ }^{2}$ Within columns and cultivars, means followed by a different letter are significantly different at the 0.05 probability level according to Tukey's studentized range test. Values are the means of three replications. 
did not significantly affect $\mathrm{Mg}^{2+}$ concentrations in the shoots (Tables 3 and 4).

Sodium concentrations in SJV waters were higher than in ICV waters (Table 1), therefore it is not surprising that shoot $\mathrm{Na}^{+}$levels in plants irrigated with the two water types are significantly different (Tables 3 and 4). Sodium in the shoots of both cultivars increased significantly as salinity increased.

Under salinity stress, maintenance of adequate levels of $\mathrm{K}^{+}$is essential for plant survival. Potassium is the inorganic plant solute present in highest concentration in plant cells (Marschner, 1995). Under saline conditions, $\mathrm{K}^{+}$makes a major contribution towards lowering the osmotic potential in root cells, a prerequisite for controlling solute transport and water balance. Potassium concentration in stock seedlings decreased significantly as salinity increased from 2.5 to $14 \mathrm{dS} \cdot \mathrm{m}^{-1}$. High levels of external $\mathrm{Na}^{+}$not only interfere with $\mathrm{K}^{+}$acquisition by the roots, but also may disrupt the integrity of root membranes and alter the selectivity of the root system for $\mathrm{K}^{+}$over $\mathrm{Na}^{+}$(Grattan and Grieve, 1999). External $\mathrm{K}^{+}$concentration was constant in this study, whereas $\mathrm{Na}^{+}$increased across salinity treatments. As a result, shoot $\mathrm{K}$ of both stock cultivars decreased significantly as salinity increased and the ratio of $\mathrm{K}^{+} / \mathrm{Na}^{+}$ in the external solution decreased. Stock appeared to be highly selective for acquisition of $\mathrm{K}^{+}$over $\mathrm{Na}^{+}$. Selectivity coefficients $\left(\mathrm{S}_{\mathrm{K}, \mathrm{Na}}\right)$ increased about $60 \%$ as salinity increased from 2.5 to $14 \mathrm{dS} \cdot \mathrm{m}^{-1}$ (data not shown). As salinity increased over the range of ICV treatments, values for 'Cheerful White' increased from 7.7 to 12.7 , and from 5.9 to 10.0 when SJV waters were used.

Shoot $\mathrm{P}$ tended to decrease with increasing salinity (Tables 3 and 4). Stock appears to have a higher $\mathrm{P}$ requirement, and to acquire $P$ from the external solution more efficiently, than other cruciferous species. For example, shoot $\mathrm{P}$ concentrations were 2- to 4-fold higher in 'Cheerful White' irrigated with SJV waters than in Brassica species (e.g., B. juncea and B. rapa) grown in sand cultures and irrigated with waters of the same composition and salinity levels (Grieve et al., 2001).

Total S in shoots of both cultivars significantly increased with salinity (Tables 3 and 4). A comparison of $\mathrm{S}$ accumulation in shoots grown with waters differing in external $\mathrm{SO}_{4}^{2-}$ suggests that stock may possess a mechanism for limiting $\mathrm{S}$ uptake. For example, the concentration of total $\mathrm{S}$ in shoots of 'Cheerful White' (i.e., $251 \mathrm{mmol} \cdot \mathrm{kg}^{-1}$ ) irrigated with ICV saline solutions containing $25 \mathrm{mmol} \cdot \mathrm{L}^{-1}$ $\mathrm{SO}_{4}{ }^{2-}$ was not significantly different from the concentration in shoots (i.e., $266 \mathrm{mmol} \cdot \mathrm{kg}^{-1}$ ) irrigated with SJV waters containing twice as much $\mathrm{SO}_{4}{ }^{2-}$ (i.e., $\left.54 \mathrm{mmol} \cdot \mathrm{L}^{-1}\right)$. Likewise, total $\mathrm{S}$ in 'Frolic Carmine' was not influenced by $\mathrm{SO}_{4}^{2-}$ concentration in the most saline treatment $\left(14 \mathrm{dS} \cdot \mathrm{m}^{-1}\right)$. Plant response to solutions differing in dominant anion concentration warrants further investigation.

Chloride in stock shoots increased significantly as salinity increased. ICV waters generally contain twice as much $\mathrm{Cl}^{-}$as $\mathrm{SJV}$ water and this difference in external $\mathrm{Cl}$ was reflected in shoot $\mathrm{Cl}$ concentrations (Tables 3 and 4).

\section{Conclusion}

The results of this study clearly demonstrate that stock is relatively salt tolerant and that this important cut-flower crop may be produced under saline irrigation without loss of quality nor reduction of marketability.

\section{Literature Cited}

Armitage,A.M. 1993. Speciality cut flowers. Varsity Press-Timber Press, Portland, Ore.

Baas, R., M.C. Nijssen, T.J.M. van den Berg, and M.G. Warmenhoven. 1995. Yield and quality of carnation (Dianthus caryophyllus L.) and gerbera (Gerbera jamesonii L.) in a closed nutrient system as affected by sodium choride. Scientia Hort. 61:273-284.
Barr, C. 1992. The kindest cuts of all: How to evaluate new crops. Greenhouse Manager 11:82-84.

Cabrera, R.I. and P. Perdomo. 2003. Reassessing the salinity tolerance of greenhouse roses under soilless production conditions. HortScience 38:533-536.

California CutFlowerCommission.2003.cfc@ccfc. org.

Flowers, T.J. and A.R. Yeo. 1988. Ion relations of salt tolerance, p. 392-416. In: D. A. Baker and J. L. Hall (eds.). Solute transport in plant cells and tissues. John Wiley \& Sons, New York.

Grattan S.R. and C.M. Grieve. 1999. Salinity mineral nutrient relations in horticultural crops. Scientia Hort. 78:127-157.

Grieve, C.M., M.C. Shannon, and J.A. Poss. 2001. Mineral nutrition of leafy vegetable crops irrigated with saline drainage water. J. Veg. Crop Prod. 7:37-47.

Heuer, B. and I. Ravina. 2004. Growth and development of stock (Matthiola incana) under salinity. Austral. J. Agr. Res. 55:907-910.

Hodges, T. 1991. Predicting crop phenology. CRC Press, Boca Raton, Fla.

Lieth, H.J. and D.W. Burger. 1989. Growth of chrysanthemum using an irrigation system controlled by soil moisture tension. J. Amer. Soc. Hort. Sci. 114:387-392.

Lunt, O.R., A.M. Kofranek, and S.A. Hart. 1954. Tolerance of six stock (Mathiola incana) varieties to saline conditions. Proc. Amer. Soc. Hort. Sci. 64:431-436.

Marschner, H. 1995. Mineral nutrition of higher plants. Academic Press, New York.

SAS Institute, Inc. 2001. SAS/STAT software. Changes and enhancements through release 8.02. SAS Inst., Cary, N.C.

Shillo, R., M. Ding, D. Pasternak, and M. Zaccai. 2002. Cultivation of cut flower and bulb species with saline water. Scientia. Hort. 92:41-54.

Suarez, D.D. and C.M. Grieve. 1988. Predicting cation ratios in corn from saline solution composition. J. Expt. Bot 39:605-612.

Suarez, D.L. and J. Simunek. 1997. UNSATCHEM: Unsaturated water and solute transport model with equilibrium and kinetic chemistry. Soil Sci. Soc. Amer. J. 61:1633-1646.

Wigdor, S., R.F. Stinson, and W.W. McCall. 1958. Chloride toxicity of flowering stock and sweet peas. Mich. Agr. Expt. Sta. Qrtly. Bul. 40:468-476. 